\title{
İmalat Firmalarında İş Sağlığı ve Güvenliği Yatırım Harcamaları İle Kaza Oranları ve İş Kazası Maliyetleri İlişskisi: İşletme Bütçesine İSG Harcamaları İçin Kaynak Tahsis Edilmesinin Önemi
}

\author{
${ }^{1}$ Metin BAYRAM, ${ }^{2}$ Hüseyin İSKENDER, ${ }^{* 3}$ Abdullah Hulusi KÖKÇAM \\ Sakarya Üniversitesi, Arifiye MYO, İş Sağ lığı ve Güvenliği Programı, ORCID ID: 0000-0002-9483-7850 \\ Sakarya Üniversitesi, İşletme Fakültesi, İşletme Bölümü, ORCID ID: 0000-0002-5654-9962 \\ Sakarya Üniversitesi, Mühendislik Fakültesi, Endüstri Mühendisliği Bölümü, ORCID ID: 0000-0002-4757-1594
}

$\ddot{\mathbf{O z}}$

Araştırmalar iş sağlığı ve güvenliğine (ISG) yapılan harcamaların maliyet olarak değil, aksine yatırım olarak düşünülmesi gerektiğini ortaya koymaktadır. İş kazaları ve meslek hastalıklarını önlemek amacıyla yapılan yatırımlar sayesinde firmaların kaza oranları ve iş kazası maliyetlerinde iyileşme sağlayarak rekabet avantajı sağlamaları mümkündür. Türkiye'de imalat sektöründe faaliyet gösteren firmalar üzerinde yapılan bu araştırma iki amaca yönelik yapılmıștır. Birincisi, yasal şartları sağlamak amacıyla yapılan İSG yatıım harcamalarına bağlı olarak kaza oranlarında ve iş kazası maliyetlerinde azalma olup olmadığı, ikincisi İSG'yi sağlamak üzere yapılan yatırım harcamaları için işletme bütçesine kaynak tahsis edilmesinin kaza oranları ve iş kazası maliyetlerinin iyileştirilmesinde bir avantaj teşkil edip etmediğidir. Veri toplama aracı olarak anket yöntemi kullanılmıştır. Türkiye'de 2017 yılı Şubat ve Ağustos döneminde, farklı büyüklükte ve NACE kodundaki 229 imalat firmasından veri toplanmıştır. Veriler tanımlayıcı ve çıkarımsal istatistik yöntemleri kullanılarak analiz edilmiştir. Katılımcı firmaların, İSG yasası ve mevzuatını tam sağlayacak kadar İSG yatırım harcaması yaptıkları, kaza oranlarında ve iş kazası maliyetlerinin her ikisinde de azalma sağladıkları bulunmuştur. İşletme bütçelerine İSG için kaynak tahsis eden firmaların istatistiki manada daha fazla İSG yatıım harcaması yaptıkları ve daha iyi kaza sıklık ve ağırlık oranları ve iş kazası maliyetlerine sahip oldukları bulunmuştur. Ölümcül / uzuv kayıplı iş kazası sayıları bağlamında İSG harcamaları için işletme bütçesine kaynak tahsis edilmesinin, istatistiki manada bir anlam ifade etmediği bulunmuştur. İş sağlığ 1 ve güvenliğine ilişkin planlı ve programlı çalışmalar yapılmasının ve işletme bütçelerine İSG için kaynak tahsis edilmesinin kaza sıklık ve ağırlık oranları ve iş kazası maliyetlerinin iyileştirilmesinde avantaj sağlandığı ampirik olarak ortaya konulmuştur.

Anahtar Kelimeler: ISG Yatırım Harcamaları, Kaza Oranları, İ̧ Kazası Maliyetleri

\section{Relationship between Investment Costs for Occupational Health and Safety with Accident Rates and Occupational Accident Costs: Importance of Allocating Resources to OHS Expenditures in Operational Budget}

\begin{abstract}
Research shows that spending on occupational health and safety (OHS) should be considered as an investment, rather than as a cost. Investments made to prevent occupational accidents and occupational diseases make it possible for firms to gain competitive advantage by decreasing accident rates and occupational accident costs. This research, which is conducted on the companies operating in the manufacturing sector in Turkey has been made for two purposes. The first is whether there is a decrease in accident rates and occupational accident costs depending on the OHS investment expenditures made in order to meet the legal requirements and the second is that whether allocating resources to the operating budget for OHS investment spending is an advantage in decreasing accident rates and occupational accident costs. Survey method was used as data collection tool. Data were collected from 229 manufacturing companies with different sizes and NACE codes in Turkey between February and August of 2017. The data were analyzed using descriptive and inferential statistical methods. It has been found that participating firms made OHS investments as much as to fulfil OHS legislation completely, and as a result reduce both accident rates and occupational accident costs. Companies that allocate resources for OHS to their operating budgets have been found to have statistically significant higher OHS investment expenditures and have better accident frequency and weight ratios, and occupational accident costs. It has been found that there is no statistically significant relationship with the allocation of resources to the operating budget for OHS spending and the number of fatal / limb loss incidents. It has been empirically demonstrated that planned and scheduled work on
\end{abstract}


occupational health and safety and allocation of resources for OHS to operational budgets are advantageous in decreasing accident frequency and weight rates and accident costs.

\section{Keywords: OHS Investment Expenditures, Accident Rates, Occupational Accident Costs}

\section{GİRIŞ}

İSG iş kazası ve meslek hastalığı yaşanmadan önce işyerlerindeki tehlike ve risklere karşı alınacak her türlü tedbir ve önlemi kapsamaktadır. İşyerlerindeki tehlike ve riskleri belirleyerek, kabul edilemez tehlike ve riskler için önlem ve tedbir almak İSG'nin öncelikli konuları arasına girmektedir. Söz konusu tehlike ve risklerin ortadan kaldırılması için risk kontrol hiyerarşisine göre sırasıyla kaynağında, ortamda ve kişi üzerinde tedbir almak gerekmektedir. Maalesef iş güvenliği tedbirleri denilince herkesin ilk aklına baret, eldiven, maske vb. kişisel koruyucular gelmektedir. Hâlbuki işyerindeki tehlike ve risklerin kontrol altına alınmasında, ilk önceliğin tehlikelerin kaynağına yönelik yatırım harcamalarına verilmesi, kişisel koruyucu donanım (KKD) kullanılması ise son çare olarak düşünülmesi gerekir. Yapılan araştırmalar (örneğin Bayram ve Ünğan [1]) işverenlerin, büyük yatırımlar gerektiren kaynakta kontrol önlemleri yerine ucuz ve temini kolay olan KKD kullanımını tercih ettiğini göstermektedir.

İş Güvenliği için yatırım yapılması, süreç ve üretim teknolojisinin doğasında değişikliklere yol açabilir. Öyle ki, bu tür yatırımlar malzeme veya enerji tasarrufu yapılarak reel maliyetlerin azalmasina neden olabilir [2]. Yetersiz güvenlik önlemlerine sahip eski teknoloji makine ve ekipmanların iş kazası ve meslek hastalığı risklerini artırdığı, büyük yatırım harcamaları gerektiren yeni teknolojilerin, çok daha ucuza mevzuata uyum konusunda firmalara yardımcı olduğu, dolayısıyla firmaların büyümesini ve rekabet gücünü artırdığ 1 düşünülmektedir [2-4]. $\mathrm{Bu}$ itibarla, işyerlerinde İSG'nin sağlanması hususunda en uygun güvenlik koşullarını sağlayan teknolojik makine, iş ekipmanı ve donanımlara yatırım yapılmalıdır [4].

İş sağlığ́ ve güvenliğine ilişkin işletme hedeflerinin başarılmasında işe başlamadan önce ISG planı yapmak en önemli tedbirlerden biridir. İşyerindeki tehlike ve riskler ne kadar önce tanımlanır ve yeterli önleyici tedbirler alınırsa, işyerinin büyüklüğü ya da kapsamı ne olursa olsun o oranda işletme amaçlarına ulaşılır. $\mathrm{Bu}$ yüzden, işyerlerinde kazalardan korunmak amacıyla etkin İSG planı yapılması ve kontrol teknikleri kullanılması; çalışanlar, işletme ve toplum üzerinde hayati etkilere neden olabilir. $\mathrm{Bu}$ bağlamda, İSG planı yapmak ISG'ye ilişkin düzenlemelere ve standartlara uyulması bağlamında temel ihtiyaç olarak sıklıkla karşımıza çıkmaktadır [5].
Dünyada (dolayısıyla Türkiye'de de) firmaların yüksek kaza oranlarına ait sonuçlar ortadadır. Bu durum iş güvenliğine yatırım yapılmasının maliyetleri artırdığına ve dolayısıyla rekabet için olumsuz etkilere yol açtığına dair firmalar arasında yanlış inanıştan kaynaklanmaktadır [2]. Halbuki, örgütün operasyonları ile entegre bir şekilde risklerin yönetilmesi hem kaza oranlarını azaltmakta hem de firmanın ekonomik ve finansal sonuçlarını iyileştirmektedir [6]. İSG'yi iyi yöneten firmalar, iş kazası ve meslek hastalıklarının maliyetlerini azaltarak karlılıklarını arttırmaktadırlar [7].

Araştırmacılar ISG uygulamalarının kaza oranları üzerinde olumlu etkileri olduğunu ortaya koymuşlardır. Bu bağlamda, Wachter ve Yorio [8] kaza oranları ile güvenlik yönetimi uygulamalarının varlığı arasında anlamlı negatif bir ilişki tespit etmiştir. Tekelioğlu [9] kaza oranlarının düşük olması ve zamanla düşme eğilimi göstermesi işletmede daha fazla iş güvenliği yatırımı yapma gerekliliğinin azaldığını, aksi durumlarda yani kaza oranlarının yüksek olması ise İSG önlemleri alınması hususunda yatırım yapma gerekliliğinin arttığını bildirmiştir. De Greef ve Van den Broek [10] yüksek kaza oranlarının çıkar sahipleri arasında firmanın durumunu bozarak rekabet açısından dezavantaja yol açabileceğini bulmuş ve bunun ISG'ye yatırım yapılması hususunda şirket yönetimini motive eden bir faktör olduğunu belirtmiştir.

İşyerlerinde kaynak tahsis etmek suretiyle İSG'yi iyi yöneten kuruluşlar, piyasada rekabet avantaj1 sağlarken, iş kazaları ve meslek hastalıklarının maliyetlerini de minimize ederek karlılıklarını arttırmaktadırlar [7]. Amerikan İş Güvenliği Mühendisleri Derneği (ASSE) yaralanma ve meslek hastalıklarını azaltmak, karlılığı artırmak ve yeni iş alanları oluşturmalarına yardımcı olmak amacıyla işletmelere İSG konusunda iş stratejisinin bir parçası olarak yatırım yapmayı önermektedir [11].

Yapılan çalışmalar İSG'ye yapılan yatırımların, iş kazaları maliyetinde ciddi oranda düşüşe neden olduğunu göstermektedir [12]. Araştırmacılar tarafindan yapılan çalışmalarda da iş güvenliği maliyetlerinin daima firma yararına olduğu gösterilmiştir [13]. Zou ve ark. [14] iş güvenliğine yatırım yapılmasının sağlayacağı faydaları; kaza sayısının azalışına bağlı olarak maliyet tasarrufu, üretimde kesintilerin azalışı ve verimlilik artışı olarak belirlemiştir. Van den Broek ve ark. [15] tarafından gerçekleştirilen iş kazaları ve meslek 
hastalıklarının sosyo-ekonomik maliyetleri konulu çalışmada ISG için yatırım yapılmasının pozitif etkileri olduğu belirtilmektedir. López-Alonso ve ark. [16] inşaat şirketi maliyetleri üzerinde ISG yatırımlarının etkisini konu alan çalışmalarında önemli sonuçlara ulaşmışlardır. Bu çalışmadan elde edilen bulgular ortalama kaza sayısının; kaza önleme maliyeti ile ters orantılı olarak değişmekte olduğunu göstermektedir.

Yukarıda anlatıldığı üzere, bu çalışmada Türkiye'deki imalat firmaları tarafindan yapılan ISG yatırım harcamalarının, işletmelerin temel amaçlarını olumlu yönde etkileyen kaza oranları ve iş kazası maliyetlerinde azalma üzerindeki etkileri üzerinde durulacaktır. Daha özelde ise, İSG yatırım harcamaları, kaza oranları ve iş kazası maliyetlerinde azalma üzerinde ISG önlemlerinin alınması amacıyla işletme bütçesine kaynak tahsis etmenin avantaj teşkil edip etmediği hususu araştırılacaktır.

\section{AMAÇ ve KAPSAM}

Türkiye'de imalat sektöründe faaliyet gösteren firmalar üzerinde yapılan bu araştırma iki amaca yöneliktir. Birincisi, İSG konusunda yasal şartları sağlamak amacıyla yapılan yatırım harcamalarına bağlı olarak kaza oranlarında ve iş kazası maliyetlerinde azalma olup olmadığıdır. İkincisi İSG'yi sağlamak üzere yıl içinde işletme bütçesine yatırım harcamaları için kaynak tahsis edilmesinin kaza oranları ve iş kazası maliyetlerinin iyileştirilmesinde bir avantaj teşkil edip etmediğidir. Spesifik olarak, Türkiye'deki imalat sektörü firmalarına yönelik yapılan bu araştırma aşağıdaki hipotezler üzerine kurulmuştur;

$\mathrm{H}_{1}$ : İşletme bütçesine İSG için kaynak tahsis eden firmalar istatistiksel manada daha fazla ISG yatırım harcamaları yapar.

$\mathrm{H}_{2}$ : İşletme bütçesine İSG için kaynak tahsis eden firmaların kaza oranları istatistiksel manada daha fazla iyileşme gösterir.

$\mathrm{H}_{3}$ : İşletme bütçesine İSG için kaynak tahsis eden firmaların iş kazası maliyetleri istatistiksel manada daha fazla iyileşme gösterir.

Türkiye'nin değişik bölgelerinde faaliyet gösteren farklı NACE kodu ve büyüklükteki imalat firmaları araştırmanın hedef kitlesini oluşturmuştur. Araştırma ile ilgili veriler 2017 yılı Şubat - Ağustos dönemlerinde toplanmıştır. Türkiye'deki imalat işletmeleri üzerinde yapılan araştırmanın İSG literatürüne olan katkısı şudur; ISG yatırım harcamaları için yıl içinde bütçe kalemi tahsis edilip edilmemesinin işletmelerin karlılık, verimlilik ve rekabet avantajı sağlama gibi temel amaçlarına ulaşmalarında olumlu katkı sağlayan kaza oranları (kaza sıklık oranı, kaza ă̆ırlık oranı ve ölümcül/uzuv kayıplı iş kazası sayısı) ve iş kazası maliyetleri (Tedavi giderleri, çallşanlara yapılan ödemeler, yönetim giderleri, işgücü kayıplarl kaynakl maliyetler, üretim kayıpları ve siparişin zamanında teslim edilememesi kaynakl maliyetler) üzerinde istatistiksel manada olumlu bir etkisinin olup olmadığını Türkiye ölçeğinde araştıran ilk ampirik çalışma olma özelliğini taşımasıdır.

\section{KURAMSAL ÇERÇEVE}

İSG maliyetleri; iş kazası ve meslek hastalığ yaşanmadan önce alınan önleyici tedbirler için yapılan harcamaları içeren önleme maliyetleri ile iş kazası ve meslek hastalığı yaşandıktan sonra işveren tarafindan katlanılan dolaylı ve dolaysız maliyetlerden oluşan iş kazası maliyetlerinin toplamıdır. Önleme maliyetleri kategorileri bir kaç yazar [17-19] tarafından incelenmiştir. Bayram et al [19] şirket düzeyinde önleme maliyetleri kategorilerini personel harcamaları, eğitim harcamaları, teknolojik yatırım harcamaları, çalışanların toplu korunması için yapılan harcamalar, KKD ve diğer iş güvenliği ekipmanlarına yapılan harcamalar, iş güvenliği işaret ve levhaları için yapılan harcamalar, dış hizmet alımı harcamaları ve yangın ve acil durum yönetimi için yapılan harcamalar olmak üzere sekiz kategoride ele almıştır. Mossink [17] ise şirket düzeyinde önleyici faaliyetlerin maliyetlerini on kategori olarak belirlemiştir. Tablo 1.'de görüleceği üzere İSG yatırım harcamaları, önleme maliyetleri sınıfı içinde yer almaktadır. Farklı olarak, Zou ve ark. [14] inşaat güvenliği üzerine yapılan yatırım maliyetlerini; İş güvenliği personel maliyetleri, İş güvenliği eğitim maliyetleri, İş güvenliği ekipmanları ve tesisleri maliyetleri, İş güvenliği konusunda yeni teknolojilerin veya araçların maliyetleri, iş güvenliği komitesi maliyetleri, iş güvenliği teşviki ve buluş maliyetleri olarak sıralanmıştır.

İş kazası maliyetleri doğrudan ve dolaylı maliyetler olmak üzere iki sınıfa ayrılır. Maliyetler tedavi masrafları, yaralıya yapılan ödemeler gibi doğrudan kazaya tahsis edilmişse, bu maliyetler doğrudan maliyetlerdir. Üretim, işgücü ve sipariş kayıpları, şirket imajının zarar görmesi vb. gibi maliyetler dolaylı maliyetleri oluşturur. $\mathrm{Bu}$ sınıflandırma önemlidir. Çünkü bu sınıflandırma kaza maliyetlerinin "gerçek" değerini belirlemek amacıyla gizli maliyetlerin araştırılması konusunda işverenleri harekete geçirebilir [20].

Bir organizasyonun İSG performans ölçüm sistemi proaktif ve reaktif olmak üzere iki ayrı izleme verilerini içerir. 
Tablo 1. Şirket düzeyinde önleyici faaliyetlerin maliyetlerine genel bir bakış (Mossink, [17])

\begin{tabular}{|c|c|}
\hline Değişken & Tanımı \\
\hline Yatırımlar & $\begin{array}{l}\text { İSG ile ilgili özel 'ISG' ekipmanlar veya diğer ilave } \\
\text { yatırımların maliyetleri }\end{array}$ \\
\hline İlave yatırımlar & $\begin{array}{l}\text { İSG ekipmanın çalışmasını kolaylaştırmak (binaların örneğin } \\
\text { rekonstrüksiyonu) üzere İSG ile ilgili olmayan sermaye } \\
\text { mallarındaki değişiklikler }\end{array}$ \\
\hline $\begin{array}{l}\text { Yatırımlarla ilgili mühendislik, } \\
\text { müşavirlik ve planlama maliyetleri }\end{array}$ & $\begin{array}{l}\text { Yeni ekipmanın veya çalışma prosedürlerinin tasarımı ve } \\
\text { uygulanması için iç ve dış faaliyet harcamaları }\end{array}$ \\
\hline İkame ürünlerin ek maliyetleri & $\begin{array}{l}\text { Fiyat farkı (örneğin; toksik-olmayan kimyasallar, daha hafif } \\
\text { ürünler) }\end{array}$ \\
\hline Kişisel koruyucu ekipman alımı & Koruyucu ekipman maliyetleri \\
\hline $\begin{array}{l}\text { Çalışma prosedürlerinde } \\
\text { değişiklikler ve bakım için ilave } \\
\text { masraflar }\end{array}$ & $\begin{array}{l}\text { Doğrudan önleyici eylemle ilgili eski ve yeni çalışma usulleri } \\
\text { arasındaki fiyat farkı. Unutulmamalıdır ki yeni yöntemler } \\
\text { maliyet tasarrufu sağlayabilir (örneğin güvenlik } \\
\text { standartlarına uygun çalışmak ekstra maliyettir) }\end{array}$ \\
\hline $\begin{array}{l}\text { Doğrudan doğruya } \\
\text { fazladan çalışma süresi }\end{array}$ & $\begin{array}{l}\text { Toplantılar, eğitim, güvenlik denetimleri, katılımc1 } \\
\text { gelişmeler için harcanan zaman }\end{array}$ \\
\hline 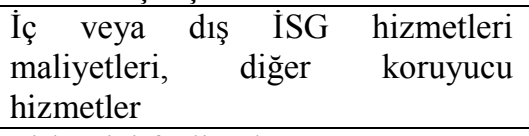 & Ayrıca iş sağlığı hizmetlerini de içerir \\
\hline Şirket-içi faaliyetler & $\begin{array}{l}\text { İnsan kaynakları yönetimi, sağlığın teşviki ve geliştirilmesi, } \\
\text { İSG politikası ve yönetimi }\end{array}$ \\
\hline Diğer işyeri masrafları & Önceki başlıklar kapsamına girmeyen her şey \\
\hline
\end{tabular}

Ölçüm ve izlemede proaktif verilerin tercih edilmesi uygun iken, İSG performansının yetersiz olduğu durumlar için reaktif izleme tercih edilmelidir. Uygulamada daha çok reaktif izleme verileri kullanılmakta olup, bunlardan bazıları iş kazası sıklı̆̆ı, iş kazası ağırlık oranı, ramak kala bildirim sayıları, işe bağ lı hastalık gün kaybı sıklığı, ortalama kişi başına gün kaybı sıklığı olarak sayılabilir [21]. Bu bağlamda, ulusal kaza istatistiklerinde de düzenli olarak izlenmekte olan ve Türkiye'deki işletmeler tarafindan yaygın olarak kullanılan reaktif izleme verileri kaza sıklık oranı, kaza ağırlık oranı ve ölümcül / uzuv kayıplı iş kazası sayısı ölçek bileşeni olarak kullanılmıştır.

Önleyici tedbirlerin alınması görevi zaman ve para kısıtları nedeniyle bazen üst yönetimin engeliyle karşllaşabilmektedir. Çünkü İSG tedbirleri için üst yönetim tarafindan yapılan harcamalar üretime doğrudan bir katma değer sağlamadığından işletmenin temel amaçlarına hizmet etmediği ve bazen katlanılması güç mali külfetler getirdiği zannedilmektedir. Ancak yazarlar tarafindan uzun dönemde firmaların iş kazası maliyetlerinin azalışına bağlı olarak karlılık, verimlilik artışı ve firma imajının iyileşmesi gibi ekonomik yararlar sağladığı belirtilmektedir [2]. López-Alonso ve ark., [16] ise İSG bütçesi ile doğru orantılı olarak ortalama kaza sayısının değişmekte olduğunu ortaya koymuştur.

EU-OSHA Direktörü Jukka Takala işletmeleri iş sağllğı ve güvenliği bütçelerinde kesintiye gitmek suretiyle kısa vadeli kazanımlar için işletmelerin uzun dönemli çıkarlarını tehlikeye atmamaları hususunda uyarmaktadır [22]. Bu bağlamda İSG'ye yapılan önleme harcamaları mali bir külfet olarak değil, firmanın geleceğine bir yatıım olarak düşünülmesi gerekir. Hatta iş kazaları temel bir endişe konusu olduğu için, kriz dönemlerinde bile Avrupalı yöneticilerin $\% 80$ 'i İş sağlığ güvenliğinden taviz verme hususunu göze almayacaklarını bildirilmektedir [22].

\section{ARASTIRMANIN YÖNTEMİ}

Veri toplama aracı olarak anket tekniği kullanılmıştır. Araştırma 2017 Şubat - Ağustos döneminde yapılmıştır. Yazarlar tarafindan tasarlanan anket formu firmaların kurumsal e-posta adreslerine elektronik ortamda ulaştırılmış olup, ihtiyaç olduğunda telefonla iletişime geçilmek suretiyle gerekli veriler toplanmıştır. Türkiye'de sanayi yönünden gelişmiş İstanbul, Ankara, İzmir, Bursa, Adana, Kocaeli, Sakarya, Manisa, Denizli, Sivas ve Balıkesir illerinde faaliyet gösteren 2250 dolayında firmaya anket formu ulaştırılmış, bunlardan 234 imalat firmasından geri dönüş sağlanmıştır. Ankete geri dönüş oranı $\% 10,4$ olarak gerçekleşmiştir. Eksik veri nedeniyle 5 anket kullanılamaz olduğundan 229 adet ankete ait veriler tanımlayıcı ve çıkarımsal istatistiksel teknikler kullanılarak analiz edilmiştir. Ayrıca toplanan verilerden işletme bütçesine İSG harcamaları için kaynak tahsis edilip edilmemesi durumuna göre firma davranışlarının istatistiki manada farklılık gösterip göstermediği analiz edilmiştir. Firmaların İSG'den sorumlu yöneticileri tarafindan cevaplanacak şekilde tasarlanan anket formu iki ana 
bölümden oluşmaktadır. Birinci bölümde firmaların demografik özellikleri, ikinci bölümünde ise ISG yatırım harcamaları, kaza oranları ve iş kazası maliyetleri ölçekleri ile ilgili sorular sorulmuştur. Araştırma, "ISSG Yatırım Maliyetleri”" ölçeği için bir, "Kaza Oranları" ölçeği ile ilgili üç ve "İş Kazası Maliyetleri" ölçeği ile ilgili altı soru olmak üzere toplam on sorudan oluşmaktadır. Ayrıca, tüm firmalara "ISSG Harcamalarınız için ayrı bir bütçe kalemi oluşturuyor musunuz?” sorusu yöneltilmiştir.

\section{1. İş Sağlığı ve Güvenliği Yatırım Harcamaları Ölçeği}

Tablo 2'de görüldüğü üzere tek bir değişkenden ibaret olan "İSG Yatırım Harcamaları" ölçeği yürürlükteki İSG Mevzuatı göz önünde bulundurularak yazarlar tarafından geliştirilmiştir. İSG Yatırım Harcamalarını ölçmek üzere, 5'li Likert ölçeği; ("1=Hiç harcama yapılmaz”, " $2=\dot{I} S G$ faaliyetleri bir maliyet unsuru olarak gözetilerek az harcama yapılır", " $3=\dot{I} S G \quad$ Kanunu yükümlülüklerini minimum sağlayacak kadar harcama yapulır", " $4=\dot{I} S G \quad$ Kanunu yükümlülüklerini tam sağlayacak kadar harcama yapılır" ve "5=Yasal yükümlülüklerin de ötesinde "Slfir İş Kazası" hedefini sağlayacak kadar harcama yapılır") kullanılmıştır.

Tablo 2. İş Sağlığı ve Güvenliği Yatırım Maliyetleri Kategorileri

\begin{tabular}{|l|c|}
\hline Açıklama & $\begin{array}{c}5 \text { 'li Likert } \\
\text { Değeri }\end{array}$ \\
\hline Hiç harcama yapılmaz. & 1 \\
\hline İSG maliyet unsuru olarak gözetilerek az harcama yapılır. & 2 \\
\hline İSG Kanunu yükümlülüklerini minimum sağlayacak kadar harcama yapılır. & 3 \\
\hline İSG Kanunu yükümlülüklerini tam sağlayacak kadar harcama yapılır. & 4 \\
\hline Yasal şartların da ötesinde sıfır iş kazası hedefini sağlayacak kadar harcama yapılır. & 5 \\
\hline
\end{tabular}

\subsection{Kaza Oranlarında Azalma Ölçeği}

Tablo 3'te görüleceği üzere, "İ̧̧ Kazası Oranlarında Azalma" ölçeği; "kaza sıklık oranı iyileşti", "kaza ağırlık oranı iyileşti” ve "ölümcül/uzuv kayıplı kaza sayısı azaldı" olmak üzere üç değişkenden oluşmaktadır. Bu ölçek Bayram ve ark. [19] tarafından geliştirilen İSG Performansı ölçeğinden uyarlanmıştır. Geçmiş dönemler ile son üç yıllık veriler karşılaştırdığında, katılımcıların bu değişkenlerle ilgili algılarını " $1=$ Kesinlikle katılmiyorum", "2=Kat1lmiyorum", " $3=\mathrm{Ne}$ katıliyorum ne katılmiyorum", "4=Kat1liyorum" ve " $5=$ Kesinlikle katıliyorum" şeklinde 5'li Likert tipi ölçekte belirtmeleri istenmiştir.

Tablo 3. İş Kazası Oranlarında Azalma Ölçeği

\begin{tabular}{|l|l|}
\hline Değişken Kodu & Değişken Adı \\
\hline ORAN_1 & Kaza Sıklık Oranı iyileşti. \\
\hline ORAN_2 & Kaza Ağırlık Oranı iyileşti. \\
\hline ORAN_3 & Ölümcül/Uzuv Kayıplı Kaza Sayısı azaldı. \\
\hline
\end{tabular}




\section{3. İş Kazası Maliyetlerinde Azalma Ölçeği}

Bu araştırmada Türkiye'deki imalat firmalarının İş Kazası Maliyetlerinde Azalma ölçeği için Bayram ve ark. (2017) tarafından geliştirilen altı değişken (Tedavi giderleri azald, Çalışanlara yapılan ödemeler azaldl, Yönetim giderleri azaldl. İsgücü kayıpları kaynakl maliyetler azald. Üretim kayıpları azaldı. Siparişin zamanında teslim edilememesi kaynakl maliyetler azaldı.) kullanılmıştır.

\section{ARAŞTIRMANIN KISITLARI}

$\mathrm{Bu}$ araştırmanın evreni Türkiye genelinde faaliyet gösteren imalat firmalarıdır. Araştırma verileri, Türkiye genelini temsil kabiliyeti yüksek sanayisi gelişmiş İstanbul, Ankara, İzmir, Bursa, Adana, Kocaeli, Sakarya, Manisa, Denizli, Sivas ve
Balıkesir illerinde faaliyet gösteren imalat firmalarından toplanmıştır.

\section{BULGULAR}

Bulgular; demografik bulgular, açıklayıcı faktör analizi, tanımlayıcı istatistiki bulgular ve çıkarımsal istatistiki bulgular olmak üzere dört başlık altında ele alınacaktır.

\subsection{Demografik Bulgular}

Ankete katılan-firmaların profili; firma büyüklüğü, faaliyet türü (NACE kodu), ISG yatırım harcaması için bütçe kalemi tahsisi, OHSAS 18001 belgesinin olmas1, anketi cevaplayan yöneticinin görevi açılarından ele alınmış olup, bunlara ait frekans ve yüzde değerleri Tablo 4'te verilmiştir.

Tablo 4. Ankete katılan firmaların profili $(N=229)$.

\begin{tabular}{|c|c|c|}
\hline Karakteristik Özellikler & Frekans & $\%$ \\
\hline İşletme Büyüklüğü (Çalışan sayısı) & 229 & 100,0 \\
\hline$<50$ & 57 & 24,9 \\
\hline $50-99$ & 35 & 15,3 \\
\hline $100-250$ & 61 & 26,6 \\
\hline $249-500$ & 41 & 17,9 \\
\hline$>500$ & 35 & 15,3 \\
\hline Faaliyet Sektörü (NACE Kodu) & 229 & 100,0 \\
\hline Ağaç Ürünleri İmalatı (14) & 6 & 2,6 \\
\hline Cam ve Seramik İmalatı (23) & 14 & 6,1 \\
\hline Deri ve Tekstil Ürünleri İmalatı $(15,16)$ & 8 & 3,5 \\
\hline Elektrikli Teçhizat İmalatı (27) & 14 & 6,1 \\
\hline Gıda Ürünleri İmalatı (10) & 20 & 8,7 \\
\hline Kauçuk ve Plastik Ürünler İmalatı (22) & 19 & 8,3 \\
\hline Kimyasal, Kauçuk ve Plastik Ürünler İmalatı $(20 ; 22)$ & 9 & 3,9 \\
\hline Madencilik $(07,08)$ & 7 & 3,1 \\
\hline Makine-Ekipman İmalatı (28) & 40 & 17,5 \\
\hline Metal Ürünler İmalatı $(24,25)$ & 73 & 31,9 \\
\hline Mobilya İmalatı (31) & 8 & 3,5 \\
\hline Diğer imalatçılar & 11 & 4,8 \\
\hline ISG Yatırımları Bütçesi & 229 & 100,0 \\
\hline İSG Yatırımları ayrı bütçe kalemi oluşturanlar & 123 & 53,3 \\
\hline İSG Yatırımları ayrı bütçe kalemi oluşturmayanlar & 106 & 46,7 \\
\hline ISG Bütçesi & 229 & 100,0 \\
\hline OHSAS 18001 belgesi olanlar & 122 & 53,7 \\
\hline OHSAS 18001 belgesi olmayanlar & 107 & 46,3 \\
\hline Anketi Cevaplayanın Görevi & 229 & 100,0 \\
\hline Genel Müdür & 21 & 9,2 \\
\hline İSG Yöneticisi & 40 & 17,5 \\
\hline İSG Uzmanı & 83 & 36,2 \\
\hline Kalite Müdürü & 26 & 11,4 \\
\hline İK Müdürü & 28 & 12,2 \\
\hline Diğer Yöneticiler & 31 & 13,5 \\
\hline
\end{tabular}

\subsection{Açıklayıcı Faktör Analizi (AFA) Bulguları}

Bu adımda, her bir gizil değişkenin bir temel faktörü paylaşıp paylaşmadığının değerlendirilmesini yapmak üzere her bir yap1 için bir AFA gerçekleştirilmiştir. AFA'dan önce, verinin faktör olabilirliğini araștırmak üzere Bartlett'in küresellik testi (Bartlett [23]) ve örnek yeterliliğini ölçmek için 
Kaiser-Meyer-Olkin (KMO) testi (Kaiser [24]) uygulanmıştır. Bulgular anlamlı bir test istatistiği göstermiştir. Bartlett'in küresellik testi için $p<0,001$ ve KMO değeri 0,912 bulunmuştur. Bu bulgular yapı tespiti için kullandığımız verilerin uygun olduğu anlamına gelmektedir. Analiz sonucunda üç adet faktörün çıkması ve döndürme yöntemi olarak da promaks rotasyonu tercih edilerek bir faktör analizi icra edilmiştir. Faktör yükleri 0,4 değerinin aşağısına sahip olan değişkenler ile birden fazla faktör üzerinde güçlü bir şekilde yüklenmiş değişkenler (> 0,400 ) hariç tutulmuştur. $\mathrm{Bu}$ prosedür, toplam varyans1 \% 85,11 olarak izah edilen 3 faktör ile sonuçlanmıştır. Dolayısıyla, bu üç faktörle toplam değişimin \%85,1'lik kısmı açıklanabilmektedir. Bu üç faktörde ilki 'IKMAL' altı bileşenden oluşmuş olup, özdeğeri 6,837 ve toplam varyansı $\% 68,37$ olarak ölçülmüştür. 'KORAN' olarak isimlendirilen ikinci faktör üç bileşenden oluşmuş olup, özdeğeri
0,911 ve toplam varyans1 $\% 9,11$ olarak ölçülmüştür. 'YATIR' olarak isimlendirilen üçüncü faktör ise tek bileşenden oluşmuş olup, özdeğeri 0,763 ve toplam varyans $1 \% 7,63$ olarak ölçülmüştür.

Katılımcilar tarafindan "Kaza Oranlarında Azalma" ve "IŞ Kazası Maliyetlerinde Azalma" ölçeklerinde yer alan değişkenlere verilen yanıtların tutarlılı̆̆ını ölçmek üzere ayrı ayrı güvenilirlik analizi yapılmış olup, analiz sonucunda Cronbach's Alpha değerleri sirasiyla 0,914 ve 0,955 olarak bulunmuştur. Dolayısıyla, her iki ölçek yüksek güvenilirlikte ölçekler olarak bulunmuştur.

\subsection{Tanımlayıcı İstatistik Analizi Bulguları}

Tüm ölçekler göz önüne alındığında, katılımcı firmalardan toplanan veriler 1şı̆ğında Tablo 5'te verilen istatistik bulgulara ulaşılmıştır.

Tablo 5. Tanımlayıcı İstatistik Sonuçları

\begin{tabular}{|l|c|c|c|}
\hline \multirow{2}{*}{ Değişkenler } & \multicolumn{3}{|c|}{ TÜMÜNDE } \\
\cline { 2 - 4 } & $\mathbf{N}$ & Ort. & Std. Sapma \\
\hline YATIR_1 İş Sağlı̆̆ı ve Güvenliği Yatırım Maliyetleri & 229 & 4,03 & 0,893 \\
\hline İş Sağlığı ve Güvenliği Yatırım Maliyetleri Ölçeği Ortalaması & $\mathbf{4 , 0 3}$ & $\mathbf{0 , 8 9 3}$ \\
\hline Kaza Oranlarında Azalma & 229 & 3,93 & 1,013 \\
\hline KORAN_1 Kaza Sıklık Oranı iyileşti. & 229 & 3,91 & 0,998 \\
\hline KORAN_2 Kaza Ağırlık Oranı iyileşti. & 229 & 4,05 & 1,052 \\
\hline KORAN_3 Ölümcül / Uzuv Kayıplı İş Kazası Sayısı azaldı. & & $\mathbf{3 , 9 6}$ & $\mathbf{0 , 9 4 2}$ \\
\hline İş Kazası Oranlarında Azalma Ölçeği Ortalaması & & \\
\hline İş Kazası Maliyetlerinde Azalma & 229 & 3,71 & 0,980 \\
\hline İKMAL_1 Tedavi giderleri azaldı. & 229 & 3,66 & 1,020 \\
\hline İKMAL_2 Çalışanlara yapılan ödemeler azaldı. & 229 & 3,59 & 1,059 \\
\hline İKMAL_3 Yönetim giderleri azaldı. & 229 & 3,67 & 1,002 \\
\hline İKMAL_4 İşgücü kayıpları kaynaklı maliyetler azaldı. & 229 & 3,64 & 1,006 \\
\hline İKMAL_5 Üretim kayıpları azaldı. & 3,43 & 1,060 \\
\hline $\begin{array}{l}\text { İKMAL_6 Siparişin zamanında teslim edilememesi kaynaklı } \\
\text { maliyetler azaldı. }\end{array}$ & $\mathbf{3 , 6 2}$ & $\mathbf{0 , 9 2 0}$ \\
\hline İş Kazası Maliyetlerinde Azalma Ölçeği Ortalaması & & \\
\hline
\end{tabular}

Tablo 5'de de görüleceği üzere, "İs sağll $\breve{g} l$ ve güvenliği yatırım harcamaları" ifadesinin ortalamas1 4,03 olarak bulunmuştur. Bu bulguya göre imalat sektöründe faaliyette bulunan firmaların İSG Kanunu yükümlülüklerini tam sağlayacak düzeyde yatırım harcaması yaptıkları anlaşılmaktadır. "Kaza oranlarında azalma" ölçeği oluşturan değişkenler KORAN_1, KORAN_2 ve KORAN_3 değişkenlerin skorları sırasıyla 3,93,
3,91 ve 4,05 ve ölçek ortalamasının ise 3,96 olarak bulunması gerek ölçek ve gerek ölçeği oluşturan değişkenler bazında katılımcılar iş kazası oranlarında iyileşme sağladıkları hususuna katıldıklarını beyan etmektedir. "IŞs kazası maliyetlerinde azalma" ifadesinin ortalamas1 3,62 olarak bulunmuştur. Ölçeği oluşturan değişkenlerin ortalamaları da "IKMAL_6 Siparişin zamanında teslim edilememesi kaynakl̆ maliyetler azald.." hariç 
3,5 değerinin üzerinde bulunmuştur. Dolayısıyla katılımcılar iş kazası maliyetlerinde iyileşme sağladıkları hususuna katıldıklarını beyan etmektedir. $\mathrm{Bu}$ bulgulardan, araştırmaya katılan imalat firmalarının İSG Kanunu hükümlerine uyum amacıyla yaptıkları yatırım harcamaları sonucunda işyerlerinde meydana gelen kaza oranları ve iş kazası maliyetlerinde iyileşme sağladıkları anlaşılmaktadır. Toplanan veriler işletme bütçelerine ISG harcamaları için kaynak tahsis edip/etmeme durumuna göre sinıflandırıldığında, Tablo 6'da verilen bulgulara ulaşılmıştır.

Tablo 6. İSG harcamaları için ayrı bir bütçe tahsis eden/etmeyen sınıflamasına göre tanımlayıcı istatistiki bulgular

\begin{tabular}{|c|c|c|c|c|}
\hline \multirow{3}{*}{ Değişkenler } & \multicolumn{4}{|c|}{ İSG için bütçe kalemi tahsis ediliyor mu? } \\
\hline & \multicolumn{2}{|c|}{ EVET } & \multicolumn{2}{|c|}{ HAYIR } \\
\hline & $\mathbf{N}$ & Ort. & $\mathbf{N}$ & Ort. \\
\hline YATIR_1 İş Sağlığı ve Güvenliği Yatırım Maliyetleri & 123 & 4,24 & 106 & 3,77 \\
\hline İSG Kanunu Uyum Maliyetleri Ortalaması & & 4,24 & & 3,77 \\
\hline \multicolumn{5}{|l|}{ İş Kazası Oranlarında Azalma } \\
\hline KORAN_1 Kaza Sıklık Oranı iyileşti. & 123 & 4,07 & 106 & 3,77 \\
\hline KORAN_2 Kaza Ağırlık Oranı iyileşti. & 123 & 4,05 & 106 & 3,75 \\
\hline $\begin{array}{l}\text { KORAN_3 Ölümcül / Uzuv Kayıplı İş Kazası Sayısı } \\
\text { azaldı. }\end{array}$ & 123 & 4,14 & 106 & 3,94 \\
\hline İş Kazası Oranlarında Azalma Ölçeği Ortalaması & & 4,09 & & $\mathbf{3 , 8 2}$ \\
\hline \multicolumn{5}{|l|}{ İş Kazası Maliyetlerinde Azalma } \\
\hline İKMAL_1 Tedavi giderleri azald1. & 123 & 3,86 & 106 & 3,54 \\
\hline İKMAL_2 Çalışanlara yapılan ödemeler azaldı. & 123 & 3,82 & 106 & 3,48 \\
\hline İKMAL_3 Yönetim giderleri azaldı. & 123 & 3,81 & 106 & 3,32 \\
\hline İKMAL_4 İşgücü kayıpları kaynaklı maliyetler azaldı. & 123 & 3,84 & 106 & 3,47 \\
\hline İKMAL_5 Üretim kayıpları azaldı. & 123 & 3,79 & 106 & 3,46 \\
\hline $\begin{array}{l}\text { İKMAL_6 Siparişin zamanında teslim edilememesi } \\
\text { kaynaklı maliyetler azaldı. }\end{array}$ & 123 & 3,63 & 106 & 3,20 \\
\hline İş Kazası Maliyetlerinde Azalma Ölçeği Ortalaması & & 3,79 & & 3,41 \\
\hline
\end{tabular}

Tanımlayıcı istatistiki analiz sonucunda üç ölçeği de oluşturan on değişkenin tamamında İSG için bütçe kalemi tahsis eden firmaların İSG Kanunu yükümlülüklerini yerine getirmek amaciyla daha fazla yatırım harcaması yaptıkları ve buna bağlı olarak son üç yıl içinde kaza oranları ve iş kazası maliyetlerinde daha fazla iyileşme sağladıkları bulunmuştur.

\section{4. Çıkarımsal İstatistik Analizi Bulguları}

$\mathrm{H}_{1}, \mathrm{H}_{2}$ ve $\mathrm{H}_{3}$ nolu hipotezleri doğrulamak üzere, İSG mevzuatına uyulması için yapılan yatırım harcamaları, kaza oranları ve iş kazası maliyetleri işletme bütçelerine ISG harcamaları için kaynak tahsis edilip edilmemesine bağlı olarak istatistiksel anlamda farklılık gösterip göstermediği analiz edilmiştir. Yapılan testlerde veriler normal dağılım göstermediğinden parametrik olmayan MannWhitney U Testi uygulanmıştır. Yapılan test sonucunda Tablo 7'de verilen bulgular elde edilmiştir. 
Tablo 7. İSG harcamaları için ayrı bir bütçe tahsis eden/etmeyen sınıflamasına göre Mann-Whitney U testi bulguları

\begin{tabular}{|c|c|c|c|}
\hline \multirow[t]{2}{*}{ Değişkenler } & $\begin{array}{c}\text { Mann- } \\
\text { Whitney U }\end{array}$ & $\mathrm{Z}$ & $\begin{array}{c}\text { Asimptotik } \\
\text { Önem (Çift } \\
\text { kuyruklu) }\end{array}$ \\
\hline & \multicolumn{3}{|c|}{ İș Sağlığı ve Güvenliği Yatırım Harcamaları } \\
\hline YATIR_1 & 4588,000 & $-4,093$ &, 000 \\
\hline YATIR_ORT & 4588,000 & $-4,093$ & ,000 \\
\hline & \multicolumn{3}{|c|}{ İş Kazası Oranlarında Azalma } \\
\hline KORAN_1 & 5344,000 & $-2,522$ & 012 \\
\hline KORAN_2 & 5406,000 & $-2,399$ & 016 \\
\hline KORAN_3 & 5998,500 & $-1,110$ & ,267 \\
\hline \multirow[t]{2}{*}{ KORAN_ORT } & 5593,000 & $-1,902$ & ,057 \\
\hline & \multicolumn{3}{|c|}{ İş Kazası Maliyetlerinde Azalma } \\
\hline $\begin{array}{l}\text { İKMAL_1 } \\
\end{array}$ & 5373,500 & $-2,475$ & ,013 \\
\hline İKMAL_2 & 5219,000 & $-2,772$ & ,006 \\
\hline İKMAL_3 & 4767,000 & $-3,722$ & ,000 \\
\hline İKMAL_4 & 5184,500 & $-2,867$ & ,004 \\
\hline İKMAL_5 & 5318,000 & $-2,541$ & ,011 \\
\hline İKMAL_6 & 5022,500 & $-3,118$ & ,002 \\
\hline İKMAL_ORT & 4799,500 & $-3,468$ & ,001 \\
\hline
\end{tabular}

Tablo 7'de görüleceği üzere işletme bütçelerine İSG harcamaları için kaynak tahsis eden imalat firmaları ile etmeyen firmalardan elde edilen veriler kıyaslandığında; değişken bazında "KORAN_3 Ölümcül / Uzuv Kayıplı İş Kazası Sayısı azaldı." değişkeni hariç diğer dokuz değişken arasında istatistiki anlamda bir farklılık bulunmuştur. Ölçek bazında ise; İSG yatırım harcamaları ve iş kazası maliyeleri ölçeği ortalamaları arasında istatistiki anlamda farklılık bulunmuş, kaza oranları ölçeği ortalamaları arasında ise $\% 5$ anlam düzeyinde anlamlı bir fark bulunamamıştır. Sonuç olarak ISG için kaynak tahsis eden firmaların, etmeyen firmalara göre bu konuda daha çok harcama yaptıkları, Bunun karşılığında iş kazaları maliyetlerinde azalma sağladıkları anlaşılmaktadır. Ancak iş kazası oranları için genel olarak net bir şey söylemek mümkün olmasada Ölümcül / Uzuv Kayıplı İş Kazası Sayısının azaldığı yönündeki iddianın dışındaki iş kaza oranlarının da azaldığ Tablo 7'deki Mann-Whitney U testi tablosundan görülmektedir.

\section{SONUÇ ve TARTIŞMALAR}

Araştırma sonuçları; Türkiye'deki imalat firmalarının genel olarak yasal mevzuat şartlarını tam sağlayacak kadar ISG yatırım harcaması yaptıklarını ortaya koymuştur. Son üç yıl içinde; kaza sıklık ve kaza ağırlık oranı, ölümcül / uzuv kayıplı kaza sayısı, tedavi giderleri, çalışanlara yapılan ödemeler, yönetim giderleri, işgücü kayıpları, üretim kayıpları hususlarında iyileşme sağlandığı görülmektedir. Siparişin zamanında teslim edilememesinden kaynaklı maliyetler konusunda ise firmaların anlamlı bir iyileşme sağlamadıkları tespit edilmiştir.

Bu çalışmada işletme bütçesine İSG harcamaları için kaynak tahsis eden imalat firmalarının, Türkiye'deki ISG mevzuat şartlarını sağlamak amacıyla istatistiki manada daha fazla kaynak tahsis ettikleri ortaya koyulmuştur $\left(\mathrm{H}_{1}\right)$. Bunun tabii bir sonucu olarak, işletme bütçelerine kaynak tahsis eden imalat firmalarının iş kazası maliyetlerinde istatistiki manada daha fazla azalma sağladıkları bulunmuştur $\left(\mathrm{H}_{3}\right)$. Kaza oranlarında azalma ölçeğini oluşturan kaza sıklık ve ağırlık oranlarının iyileştirilmesinde işletme bütçelerine kaynak tahsis edilmesinin istatistiki manada avantaj sağladığı, fakat ölümcül / uzuv kayıplı iş kazası sayısının azalmasında istatistiki manada bir etkisi olmadığı sonucuna ulaşılmıştır. Kaza oranlarında azalma ölçek ortalaması dikkate alındığında, işletme bütçesine kaynak koymanın istatistiki manada olumlu bir etkisinin olmadığı ortaya konulmuştur. $\mathrm{Bu}$ itibarla $\mathrm{H}_{2}$ nolu hipotez reddedilmiştir.

$\mathrm{Bu}$ çalışma ile, işletme hedeflerinin başarılması hususunda iş sağlığ 1 ve güvenliğine ilişkin planlı ve programlı çalışmalar yapılmasının ve işletme bütçelerine kaynak tahsis edilmesinin kaza sıklık ve ağırlık oranları ile iş kazası maliyetlerinin iyileştirilmesinde avantaj sağlandığı ampirik olarak ortaya konulmuştur.

$\mathrm{Bu}$ araştırmadan elde edilen bulgular iş güvenliğine yatırım yapılmasının kaza oranları üzerinde olumlu etkileri olduğunu ortaya koyan Wachter ve Yorio [8] çalışmasını desteklemektedir. Ayrıca, firmalara rekabet açısından dezavantaja yol açan yüksek kaza 
oranlarının İSG'ye yatırım yapılması hususunda şirket yönetimini motive eden bir faktör olduğunu belirten De Greef ve Van den Broek'in [10] söylemleri ile tutarlıdır.

$\mathrm{Bu}$ çalışma aynı zamanda iş güvenliğine yatırım yapılmasının sağlayacağı faydaları maliyet tasarrufu, üretimde kesintilerin azalışı ve verimlilik artışı olarak belirten Zou ve ark. [14], İSG için yatırım yapılmasının sosyo-ekonomik maliyetler açısından pozitif etkileri olduğunu belirten Van den Broek ve ark. [15] ve ortalama kaza sayısının kaza önleme maliyeti ile ters orantılı olarak değişmekte olduğunu ortaya koyan López-Alonso ve ark. [16] çalışmalarını desteklemektedir.

Gelecekte bu konu üzerinde çalışma yapmak isteyen araştırmacıların metal, maden, inşaat gibi belirli sektörler üzerinde benzer çalışmaları yapmaları önerilmektedir.

\section{REFERANSLAR}

[1] M. Bayram ve M. C. Ünğan, "İSG Yönetim Sistemi Uygulayan Firmaların İş Sağlığı Ve Güvenliği Maliyetleri Tutumlarının İncelenmesi" 1. Uluslararası İş Güvenliği ve Çalışan Sağlığı Kongresi, Kocaeli, Türkiye, 273-283, 2016.

[2] B. F. Muñiz, J. M. Montes-Peón, and C. J. Vázquez-Ordás, "Relation between occupational safety management and firm performance", Safety science, 47, 980-991, 2009.

[3] N. Gerek, İşçi Sağlığı ve İş Güvenliği, Anadolu Üniversitesi Açıköğretim Fakültesi, ISBN: 97506-0383-4, Eskişehir, 2006.

[4] E. Biçer, "İş Kazalarının Nedenleri Maliyeti ve Önlenmesi Üzerine Çalışma”, Yüksek Lisans Tezi, Gazi Üniversitesi, Fen Bilimleri Enstitüsü, 2007.

[5] I. Kamardeen, "E-OHS planning system for builders", Architectural Science Review, 54(1), 50-64, 2011.

[6] M. O'Toole, “The relationship between employees' perceptions of safety and organizational culture", Journal of Safety Research 33, 231-243, 2002.

[7] C. Boyar, "6331 Sayılı İş Sağlığı ve Güvenliği Kanununun Matbaacılık Sektöründe Devlet İşçi İşveren Arasındaki İlişki” Bitirme Projesi, Yeni Yüzyıl Üniversitesi, Sağlık Bilimleri Enstitüsü, 2014.

[8] J. K.Wachter, and P. L. Yorio, "A system of safety management practices and worker engagement for reducing and preventing accidents: An empirical and theoretical investigation", Accident Analysis \& Prevention, 68, 117-130, 2014.
[9] M. Tekelioğlu, "İşçi Sağlığı ve İş Güvenliğinin Ekonomik Boyutu”, Mühendis ve Makine, 35(419), 31-34, 1994.

[10] M. De Greef, and K. Van den Broek, "Quality of the working environment and productivity: Research findings and case studies" European Agency for Safety and Health at Work, 1-87, 2004.

[11] D. Hurns, "Investment In Workplace Safety Triggers Positive Bottom Line Results For Businesses, Economy, Safety Official Notes", ASSE [Internet] 2004 Mar 23, https://www.asse.org/newsroom/releases/press 362.htm, (Erişim zamanı; Eylül, 01, 2014).

[12] M. Koç, ve N. Akbıyık, "Türkiye'de İş Kazalarının Maliyetleri ve Çözüm Önerileri”, Journal of Academic Approaches, Winter 2011, 2(2), 129-175, 2011.

[13] Ş. Cingıllioglu, "Health And Safety Cost Evaluation In Construction Projects Case Study: Oman DMIA Project" M.Sc. Thesis, Istanbul Technical University, Graduate School of Science Engineering and Technology, 2012.

[14] P. X. W. Zou, V. Y. Shi, and Z. Li, "An econometric evaluation framework for investment in construction safety", In: Editor EC. Procs 26th Annual ARCOM Conference; 2010 Sep 6-8; Leeds (UK): Association of Resers in Construction Management, 2010.

[15] K. Van den Broek, M. De Greef, and S. Van Der Heyden, "Final Report Socio-economic costs of accidents at work and work-related ill health VT-2008/066", European Commission Directorate-General for Employment, Social Affairs and Inclusion, Benefits of Occupational Safety and Health (benOSH), 1-217, 2011.

[16] López-Alonso, M., Ibarrondo-Dávila, M. P., Rubio-Gámez, M. C., and Munoz, T. G., "The impact of health and safety investment on construction company costs". Safety science, 60, 151-159, 2013.

[17] J. Mossink, "Inventory of Socioeconomics Costs of Work Accidents", European Agency for Safety and Health at Work, Topic Centre on Research — Work and Health, 1-47, 2002.

[18] G. D. Panopoulos, "Economic Aspects of Safety in Greek Construction Industry", Doctor of Philosophy. Aston (UK): Aston University, 2003.

[19] M. Bayram, M. C. Ünğan and K. Ardıç, "The relationships between OHS prevention costs, safety performance, employee satisfaction and accident costs", International Journal of Occupational Safety and Ergonomics, 23(2), 285-296, 2017. DOI: 10.1080/10803548.2016.1226607

[20] M. Battaglia, M. Frey, and E. Passetti, "Accidents at work and costs analysis: a field 
study in a large Italian company", Industrial health, 52(4), 354-366, 2014.

[21] Ş. Özdemir, ve H. Topçuoğlu, "İş Sağlığı ve Güvenliği Performans Ölçümü ve İzleme", Mühendislik ve Makina, 50(592), 30-33, 2009.

[22] L. Walter, (2010) "EU-OSHA: Safety and Health Spending is an Investment, Not a Cost" http://www.ehstoday.com/international/news/e u-osha-safety-health-spending-investment4021 (Erişim zamanı; Ağustos, 28, 2017).

[23] M. S. Bartlett,. "A note on the multiplying factors for various chi square approximations", Journal of the Royal Statistical Society, 16(Series B), 296-298, 1954.

[24] H. F Kaiser, "An index of factorial simplicity", Psychometrika, 39(1), 31-36, 1974. 